\title{
Interplay of Two Socio-Political Movements: Khudai Khidmatgar Movement and Independence Movement
}

\author{
Nauman Reayat \\ Abdul Wali Khan University Mardan, Pakistan \\ Anwar-ul-Mujahid Shah \\ Bacha Khan University Charsadda, Pakistan \\ Usman Ali \\ Quaid-i-Azam University, Pakistan
}

\section{INTRODUCTION}

The North West Frontier Province lies in the North of Pakistan, with Afghanistan to its West, Punjab and Kashmir to its East, and Baluchistan to its South. The region "designated" by the colonial rulers of India as the North-West Frontier Province has played a significant role in the making of Indian history. From the annexation of the Punjab in 1849 until 1901, the Pashto-Speaking Frontier districts of Peshawar, Kohat, Banu, Hazara and Dera Ismail Khan remained within Punjab province. The Punjab had also control over the border tracts of Malakand, Khyber, Kurram, North Waziristan and South Waziristan. Lord Curzon the Viceroy of India had the knowledge of the area. He was well aware of the fact that for better administration, NWFP should be separated from the Punjab. Thus, as a result of Curzon's initiative, on $9^{\text {th }}$ November, 1901 the North West Province came into being(Bakhsi, 1992).

The Khudai Khidmatgar movement emerged as strong political force in NWFP. It was founded by Abdul Ghaffar Khan commonly known as Bacha Khan. He was born in 1890 at Utmanzai (Charsada) in the Peshawar district. He was the fourth child of his parents(ibid). His father Bahram Khan was a well-to-do landowner of Mohammadzai clan. He received his early education in Peshawar. For higher education, he intended to go to England where his elder bother Khan Sahib was doing his MBBS but due to his mother unwillingness he was not allowed to go abroad. She believed that a person who went aboard, particularly to England never come back(ibid). Thus Abdul Ghaffar Khan had to give a second thought to his trip 
to England, indeed, he vowed to uplift the educational status of people living in his province who were uneducated and indulged in inter-tribal factional wrangling and feuds. Other time-wasting activities of the people living in his province also prompted and motivated him to decide his trip to England. His decision was driven by his desire and aspiration for educational development of Pushtuns.

\section{KHAILAFAT MOVEMENT}

Khailafat movement was launched in 1919, for the protection of Holy places and Khailafat in Turkey. But Britian did not maintain their promise due to which Hijrat movement took place. This movement ended in complete failure. However, it provided an opportunity to organize them politically.

Many other minor organziations such Majlis-i-Ahrar-Islam which was established at Lahore in 1929 and Khaksars was established in April 1931 to safeguard the rights of Muslims in NWFP to create an Islamic state.

\section{FORMATION OF KHUDAI KHIDMATGAR MOVEMENT}

In November 1929, another organization known as the Khudai Khidmatgar was formed. The British called them as red shirts(Amin, 1988). The organization got Sarfaraz Khan as its first president to lead and Hijrab Gul as its first secretary to liaison with other individuals and groups. Main source of its rapidly gaining popularity was their committed stance on promotion of Pushtun nationalism and elimination of social evils. This new organization quickly became very popular. The organization worked for the promotion of Pushtun nationalism and eradication of social evils from the society. The most important slogan of the movement was the withdrawal of colonial power from India. There is no definite and concrete information about exact numbers of branches and members of this organization(Shah,1999). But by consulting sources, it reveals that membership reach from twelve to fifteen hundred. Discipline was the fundamental functional tool in Khudai Khidmatgar for cohesive and organized performance of the organization. Organizational training of the members and associates was carried out along the military lines. But they bore no arms, carried no weapon not even a lathi(Tendulkar , 1967). Like an organized and committed military or a group of comrades, associates and members were given ranks of captain, generals and colonels etc. They were bound to commit themselves to abstinence from violence, use of drugs and other major sins of the society. The British government made an 
extensive propaganda against the movement and dubbed them as Russian agents (Shah,1999).

The most significant feature of the movement was their adoption of nonviolence(Banerjee,2000)It is said that Abdul Ghaffar Khan was inspired from Ghandhi's conception of non-violence that is why he adopted this but actually he was inspired from the life of Prophet (P.B.U.H) not from the Ghandi(Ibid).

\section{ROLE OF ABDUL GHAFFAR KHAN}

In December 1929, Abdul Ghaffar Khan and other prominent members of Khudai Khidmatgars attended the Lahore session of Congress. One of the main purpose of the Bacha Khan and the Khudai Khidmatgar's participation was to attract the Indian opinion about the Frontier atmosphere. The met the Congress leaders and sought their help in this connection. The Congress high command promised to send a Committee to enquire into their grievances. Abdul Ghaffar Khan was impressed by this initiative of the Congress.

Spring of 1930 saw beginning of civil obedience movement by Gandhi against the colonial power. Khudai Khidmatgars were also invited and they participated in it. During this civil disobedience movement Qissa Khwani Bazar (Peshawar) massacre took place leading to hundreds of casualties and deaths by the colonial government(Wikipedia retrieved on July 7,2016). What happened at Qissa Khwani Bazar in the shape of a massacre was not the end. That incident was followed by another major incident of firing incident which led to killing of another twelve persons on May 31, 1930. In the aftermath sheer instability led to declaration of martial law under which the province was disconnected from rest of the subcontinent. Numbers of Khudai Khidmatgars increased massively due to national and international developments one of which was the repression.. Before April 23, 1930, the Khudai Khidmatgars were about twelve hundred, after the repression, their number exceeded to twenty five thousand.

Seeing the growing popularity of khudai khidmatgars, government promptly responded to ongoing events by sending Abdul Ghaffar Khan to the Gurat prison. Meanwhile, two other active and forefront members of the movement Mian Jaffar Shah and Abdullah Shah managed to meet Bacha Khan at prison and discussed with him the political situation in the N.W.F.P. Abdul Ghaffar Khan authorized the affiliation of their organization with a political body of national level and importance in India. Mian Jaffar Shah went to meet Malik Lal Khan, an important activist of Khilafath movement and through him they met Sir Fazli Hussain, an 
influential member of executive arm of Viceroy's council. But he refused any help against the British government. Their next choice was Congress, which had already been involved in the affairs of the Frontier. They welcomed Abdul Ghaffar Khan and other Khudai Khidmatgar leaders released in March, 1931. All India National Congress invited the Khudai Khidmatgars to their annual session at Karachi. On 30 March, Abdul Ghaffar Khan was asked to openly declare his association with Congress which he did. On 9 August, 1931, the Khudai Khidmatgars were federated with Congress. Abdul Ghaffar Khan was made the leader of the organization in N.W.F.P.(Moore, 1974).

Bacha Khan was criticized by a section of the Frontier Muslims for making alliance between Khudai Khidmatgars and All India National Congress. Abdul Ghaffar Khan responded to the allegations and said that Pushtuns needed help from the outside the province and further he cited examples from the life of the Holy Prophet (PBUH) who made alliances with Jews and Christians to safeguard the interests of the Muslims. So, according to the Bacha Khan it was not sinful to join hands with Hindus, Abdul Ghaffar Khan, due to his dedication to the cause of freedom and his adoption of non-violence as creed, was bestowed the title of "Frontier Ghandi"(ibid).

\section{KHUDAI KHIDMATGAR-MUSLIM LEAGUE CONFLICT}

A majority of the Frontier Muslim were against the role of title-holders and the big Khans in the League Organization, which gave the Muslim League a poor image in the eyes of public. Jinnah was informed that the Frontier Muslims were tired of such type of people and they have no faith in these jagirdars, nawabs and was requested to bring the party to the masses. On 21 February a meeting of the Frontier Provincial Muslim League was convened at Peshawar and Qayyum was appointed as the League's leader in the provincial assembly. Since any change within the legislative assembly was impossible, and the next elections were at least four years away, the Frontier Provincial Muslim League started preparations for unconstitutional methods to be used against the Frontier Congress Ministry. The purpose of this Civil Disobedience Movement was to popularize Muslim League in the province and also remove the sympathies of the people for the Khudai Khidmatgars. Amin al-Hasanat commonly known as Pir of Manki Sharif played an important role in popularizing the Muslim League in N.W.F.P. He advised his disciples and murids to join Muslim League instead of Congress because the latter is a Hindu dominated party. Similarly, women of the N.W.F.P also played a vital role in the Muslim League. This was the first time in history that women of this 
area took part in political activities because in N.W.F.P women are only confined to the four walls of a house(Shah, 1999).

Caroe the Governor of N.W.F.P was convinced of the rise in the popularity of the Muslim League and the waning influence of Khan Brothers in the Frontier. Caroe warned Dr Khan Sahib of the growing influence of the Muslim League and advised him to allow public meetings and announced holding of fresh elections in the province but he (Dr Khan Sahib) flatly refused his advice. Caroe knew that the Congress Ministry will be dissolved within few days. He informed the Viceroy about the situation(ibid). After a long discussion with Governor, Ismay recommended to the Viceroy that Governor should be allowed to use his special powers, by dissolving the Frontier Ministry and declaring Governor Rule in N.W.F.P. He further suggested that in order to maintain peace in a province, a coalition government of the League and Congress should be formed, or an announcement should be made by the Governor for holding fresh elections before the transfer of power. One of the most important task before Mountbatten was to peacefully transfer power to Indian hands. On his arrival in India he found the Frontier to be a battleground between the Muslim League and Congress. The Governor of the N.W.F.P presented a gloomy picture of the latest situation of the province where the administration was nearing the breaking point in the Governor's conference which was held in Delhi on 16 April. His proposed solution was an announcement of the holding of fresh elections in the Frontier. Nehru also agreed with the Viceroy's suggestion of holding fresh elections in the province to obtain the real views of the electorate on whether to join a Hindustan or a Pakistan.

\section{LORD MOUNTBATTEN'S RESPONSE}

To know about the situation in the Frontier, Mountbatten decided personally to visit the province. He requested Jinnah to ask his followers to refrain from violence. The Muslim League in N.W.F.P decided to stage huge demonstration on the occasion of the Viceroy's visit. The main purpose was to convince the Viceroy that the overwhelming majority of the Muslims of N.W.F.P were behind the League's demand for the dissolution of Dr. Khan Sahib's government and the merger of their province with Pakistan. The Viceroy, on his arrival to Peshawar on 28 April went straight to the Governor's house. He found Caroe in state of anxiety an agitation(ibid). The League members insisted to see the Viceroy. But Khan Sahib advised him not to appear before them in order to avoid the possibility of a clash between the Leaguers and the Khudai Khidmatgars. However, the Viceroy just stood far away from the crowd and waving to them for a few minutes. The 
Leaguers greeted him by raising slogans of Mountbatten 'Zinda Bad'and Pakistan 'Zinda Bad' (www.asiareflection.com retrieved on July 7,2016). Mountbatten met with the Governor, Ministers and the tribal delegations and promised that within two months they would receive details of the procedure for the transfer of authority. According to the Viceroy, it was not due to the pressure of Muslim League but due to the British Government directives to transfer power in manner which he Indian people wanted.

After his visit, Mountbatten sent Ismay to London with his partition plan, including fresh elections in the N.W.F.P. Viceroy had also a meeting with Jinnah and Liaquat Ali Khan. He informed them of his decision to hold fresh election. The purposed election according to Mountbatten would be holding on 'Pakistan or Hindustan'. Soon after this 3 June plan was announced in which it was decided by the British government to transfer the power into the hands of Indians immediately. 15 August was chosen as the earliest possible date for that purpose. In case of N.W.F.P it was also recommended the holding of referendum on issue of joining India or Pakistan. Mountbatten, on 2 June summoned the representatives of the Congress, the All India Muslim League and the Sikhs and asked for their comments. Nehru, representing the Congress, accepted the plan. Baldev Sing also accepted it. Jinnah informed the Viceroy that after consulting All Indian Muslim League Council then he would be able to give the response. However, he promised his help(Tendulkar, 1967). Mountbatten next met Ghandi who was against partition. The Viceroy used tact to persuade Ghandi not to act against partition as such an action would lead to violence.

\section{HOLDING OF PLEBISCITE AND PUSHTUNISTAN ISSUE}

League was satisfied by the announcement of the holding of a plebiscite on the choice of India or Pakistan, the Khudai Khidmatgars were indignant. The Frontier Congress was left with no other option but to adjust itself to the changing circumstances. With the announcement of the British withdrawal from India one of the main objectives of the Khudai Khidmatgar seemed to be fulfilled. From the beginning they had favoured a United India. But with the announcement of division of the subcontinent into Pakistan and India, the Khudai Khidmatgars started re-thinking their own future. So their slogan changed from United India to autonomous Pushtunistan(The Frontier Post (Peshawar). 14 March 1992).To their chagrin the Congress had accepted the partition plan including a referendum in the N.W.F.P, without even consulting them. However, Ghandi opposed the referendum. According to him, it would be unfair to ask the Pushtuns to choose 
between Hindustan and Pakistan without knowing what each is. They should at least know where their rights will be fully protected. Differences thus emerged between the Ghandi and the Congress on the issue of referendum and these differences increased to such an extent that Ghandi decided to go to Bihar to spend his time in relief. Abdul Ghaffar Khan was stunned at the decision of the Congress as they had always been in a political understanding that they would not leave Khudai Khidmatgars in lurch by accepting the partition of India. Feeling betrayed, Bacha Khan accused All India National Congress of treachery because Congress kept Bacha Khan and his followers in dark about its approach and it also didn't take Khudai Khidmatgars into confidence and consultation. The Khidmatgars were actually disappointed because they were left behind by Congress high and dry at the end. Abdul Ghaffar stated that Pakhtuns acted reliable, consistently and predictably in their struggle for freedom, alliances and sacrifices but Congress broke his trust and that of his followers.He lamented that Congress, by accepting the partition plan, threw them to wolves (www.jstor.org retrieved on July 7,2016). For him, wolves were that landed class which would probably carry the colonial legacy. He was against the idea of holding referendum because he though that Khudai Khidmatgars had already fought the 1946 elections on the same issue of selection of joining. He was of the view that Muslim League's one point agenda in 1946 election was Pakistan and as they didn't ally with Muslim League and won the election in N.W.F.P then that itself showed the decision. Now, as partition plan had been accepted by two major parties, Congress and Muslim League, then there was no need to go for a referendum. Instead, options should be of Pakhtunistan or Pakistan i.e. living independently or with Pakistan.

\section{JINNAH-GHAFFAR MEETING}

A meeting between Abdul Ghaffar Khan and Quaid-i-Azam, Mohammad Ali Jinanh took place on June 18. Abdul Ghaffar Khan clarified to Jinnah that Khudai Khidmatgars wanted to join Pakistan but they had some conditions for the future government on which they would join Pakistan. Those conditions included compete autonomous government structure of the province in federal setup, right of secession from the federation whenever it is demanded and the right to admission to the N.W.F.P of territories inhabited by Pushtuns. Jinnah asked him first to join the Constituent Assembly of Pakistan and then to decide all these matters with mutual understanding(Bakhshi, 1992). Abdul Ghaffar Khan replied that after consulting his party, he would inform him. A meeting of the khudai Khidmatgars was held at Bannu on June 21. Abdul Ghaffar Khan put before the participants the details of partition and post-partition picture. After knowing the details of the plan, 
the participants were very disappointed over the stance of Congress. Majority of participants came up consensually with their own idea of Islamic State of Pushtunistan which would have a separate constitution rooted in culture and traditions of locales. It was further decided to boycott the referendum because there was no option of Pushtunistan in the referendum(Shah, 1999). Jinnah reacted sharply to this decision of Khudai Khidmatgars and appealed to the Muslims of the N.W.F.P to support the referendum in favour of Pakistan, as they were Muslims first and Pushtuns later. Under the supervision of the Army, the referendum was held between 6 and 17 July and its results were announced on 20 July. The Congress did not take part in the polling. According to the official results, the votes polled in favour of Pakistan were 50.49 percent of the total electorate. Therefore, Pakistan emerged on the map of the world on $14^{\text {th }}$ of August 1947 as an independent country. The result was clear proof of the Pushtun support for Pakistan. The Khudai Khidmatgars, however, regarded the referendum as one sided affair. According to Dr.Sahib bogus votes were cast(ibid).

The Khudai Khidmatgars gathered at Sardaryab (Peshawar) to discuss the future strategy and stance on newly independent country. They decided to be loyal citizens of new country . On February 23, 1948, Abdul Ghaffar Khan attended the first session of Pakistan Constituent Assembly, held at Karachi and took oath of allegiance to the state of Pakistan(The Frontier Post (Peshawar). 14 March 1992.). Quaid-i-Azam Mohammad Ali Jinnah was impressed from positive, amiable and embracing attitude of Abdul Ghaffar Khan so much so that he invited him to meal. In response, Abdul Ghaffar Khan invited Quaid-i-Azam Mohammad Ali Jinnah for a visit to N.W.F.P and insisted to spend sometime with Khudai Khidmatgars for a first-hand and direct observation. Honoring the invitation, Jinnah visited N.W.F.P in April 1948 and met Abdul Ghaffar Khan in Peshawar. Jinnah was reluctant to meet Khudai Khidmatgars. During the meeting, Jinnah proposed Muslim League membership to Ghaffar Khan but he didn't accept to join Muslim League(Shah,1999).

\section{ABDUL GHAFFAR KHAN MEETING WITH ABDUS SAMAD KHAN ACHAKZAI}

Number of meetings took place between Abdul Ghaffar Khan, Abdus Samad Khan Achkzai and G.M.Syed and other nationalist leaders in March 1948. Major purpose of those meetings was to forge unity among divergent nationalist leaders. Motivation was to build up a front against Muslim League government. Those joint struggle gave rise to emergence of Pakistan People Party(Amin,1988). Abdul 
Ghaffar Khan became its president and G.M Syed its secretary. In order to popularize the new party, he started a tour of the N.W.F.P. However, he was arrested near Kohat on June 15, 1948 and sentenced to three years imprisonment. Both Khudai Khidmatgar organization and Pakistan People Party was banned(ibid). It was not the end rather a beginning of facing the music. When his term of imprisonment expired, he was put behind the bar for another of three years. He had been released in 1954. As soon as he had been released, he joined anti-One Unit movement(Haq,1989). He criticized the integration of the West Pakistan into one single administrative unit. In March 1954, Bacha Khan attended the Constituent Assembly session. He addressed the house in which he said "that whoever hears the name of Bengal knows that it is the land of the Bangalis; whoever hears the name of Punjab knows that it is the land of the Punjabis; whoever hears the name of Baluchistan knows that it is the land of Baluchis; whoever the name of Sindh knows that it is the land of Sindhis. In this way we too have a country of our own but it has no name of its own. No one visualize our country, the country of Pathans, unitl it has an expressive name of its own i.e. Pushtunistan(The Frontier Post (Peshawar). 14 March 1992).

Abdul Ghaffar Khan died on January 1988, at the age of 98 years(ibid). He was buried at the Shisham Bagh (Afghanistan) through he died but he left behind his followers who still dominate the N.W.F.P politics as a political legacy(ibid).

\section{References and notes:}

Amin, Tahir.(1988).Ethno-National Movement of Pakistan: Domestic and International Factors. Islamabad: Pap- Board Press.

Bakshi, S.R.( 1992). Abdul Ghaffar Khan: The Frontier Ghandi. New Delhi: Anmol Publication.

Banerjee, Mukulika.(2000).The Pathan Unarmed. Karachi: Oxford University Press, 2000.

Moore, R.j. (1974).The Crisis of Indain Unity 1917-1940. London: Oxford University Press.

Moinul Haq, Haq, S.(1989). "Ideological Basis of Pakistan in Historical Perspective". Pakistan

Historical Society.Karachi: New Housing Society (Jan 1989): 70-75

Shah, Sayed Wiqar Ali.(2007) North West Frontier Province: History and Politics.

Islamabad:Gawalmandi Press.

Shah, Syed Wiqar Ali.(1999) Ethnicity, Islam, and Nationalism: Muslim Politics in the North-

West Frontier Province 1937-1947. Karachi: Oxford University Press.

Tendulkar, D.G.(1967) Abdul Ghaffar Khan: Faith is a battle. Bombay: The Times of Indian Press. 
The Frontier Post (Peshawar). 20 January 1992.

http://en.wikipedia.org/wiki/Qissa Khwani Bazar massacre

http://www.asianreflection.com/prismsprisons.pdf

http://www. Jstor.org/view/00219118/di973721/97p0126y/0

\title{
Summary
}

\section{Interplay of Two Socio-Political Movements: Khudai Khidmatgar Movement and Independence Movement}

\author{
Nauman Reayat \\ Abdul Wali Khan University Mardan, Pakistan \\ Anwar-ul-Mujahid Shah \\ Bacha Khan University Charsadda, Pakistan \\ Usman Ali \\ Quaid-i-Azam University, Pakistan
}

\begin{abstract}
Khudai Khidmatgar Movement was an important historical movement which mobilized the polity in a bottom-up direction to awaken the people living in the then North Western Province and today's province of Khyber Pakhtunkhwa. Khan Abdul Ghaffar Khan was a transformational and charismatic leader. He educated common people about non-violence as a tool for organization and accomplishment of designed objectives. The essence of whole movement was rooted in the religion Islam which is interesting against the background of inspiration drawn by Pushtuns nationalists for the legitimacy of their narratives. This work throws new light on historical legacy of Khudai Khidmatgar Movement led by Khan Abdul Ghaffar Khan from a leadership perspective through historical comparative method. A new insight will be made to dig out various methods adopted by the leadership of the movement to gain the legitimacy of the movement and which had roots in religious text.
\end{abstract}

Key words: Khudai khidmatgar movement; independence movement; nationalism; nonviolence 